\title{
Acquisition Returns: Does Industry Matter?
}

\author{
This version: February 2012
}

\author{
Reza Yaghoubi a,1, Stuart Locke ${ }^{\text {a }}$, Jenny Gibb ${ }^{\text {a }}$ \\ ${ }^{\text {a } W a i k a t o ~ M a n a g e m e n t ~ S c h o o l, ~ T h e ~ U n i v e r s i t y ~ o f ~ W a i k a t o, ~ P r i v a t e ~ B a g 3105, ~ H a m i l t o n, ~ N e w ~ Z e a l a n d ~}$
}

\begin{abstract}
:
Despite the large number of studies on acquirers' return from acquisitions, the role of industry specifications in post-completion return of acquisitions remains underexplored. Recent studies provide evidence of differential performance across industries. However, a relationship between acquirer performance and its industry is still indeterminate. This research uses a longer time period and a broader range of industries than previous studies. It illuminates the issue of whether there is a significant difference between long-term abnormal return of acquirers across industries, and which industries achieve better returns.

JEL classification: G34
\end{abstract}

Keywords: Acquisitions; Abnormal returns; Industry

\section{Introduction}

Despite the large number of studies on wealth gains from acquisitions, the role of industry in post-completion returns of acquirers remains underexplored. Recent studies provide evidence of differential performance across industries. For example, extant literature provides evidence of neutral, significantly positive, and significantly negative post-completion abnormal returns , respectively in banking (e.g. DeLong, 2003), property-liability insurance (Boubakri et al.,

\footnotetext{
${ }^{1}$ Corresponding author. Address: Dept. of Finance, Private Bag 3905, Hamilton, New Zealand, Email: reza@waikato.ac.nz; Phone: +64 21122 0567; Fax: +64 78384331.
} 
2008; Cummins and Xie, 2008) and telecommunications (Ferris and Park, 2001) industries. However, a relationship between acquirer performance and its industry is still indeterminate. This is because the previous studies often did not take industry into consideration or used samples from one or two particular industries. This research uses a longer time period and a broader range of industries than previous studies. The sample of this study comprises 3142 acquisitions by firms from the New York Stock Exchange (NYSE), The American stock Exchange and Nasdaq and completed during July 1981 - December 2007. It illuminates the issue of whether there is a significant difference between long-term abnormal return of acquirers across industries, and which industries achieve better returns.

The appropriate methodology for calculating long-term abnormal returns has been a topic of dialectic debate in the literature ${ }^{2}$. A number of scholars (e.g. Fama, 1998; Mitchell and Stafford, 2000) advocate cumulative abnormal returns (CARs) approach which answers the question of whether the sample firms persistently earn abnormal monthly returns. On the other hand, a number of researchers (e.g. Barber and Lyon, 1997; Loughran and Ritter, 2000) propose the use of buy-and-hold abnormal returns (BHARs), which more precisely measures investor experience. Since the discussions on the pros and cons of these two methods are contradictory and inconclusive, and essentially each answers a different question, this research uses both methods in an attempt to make robust conclusions regarding long term abnormal returns of acquisitions.

\footnotetext{
${ }^{2}$ For a complete discussion on the topic see Barber and Lyon Barber, B.M., Lyon, J.D., 1997. Detecting longrun abnormal stock returns: The empirical power and specification of test statistics. Journal of Financial Economics 43, 341-372., Kothari \& Warner Kothari, S.P., Warner, J.B., 1997. Measuring long-horizon security price performance. Journal of Financial Economics 43, 301-339., Fama Fama, E.F., 1998. Market efficiency, long-term returns, and behavioral finance. Journal of Financial Economics 49, 283-306., Lyon, Barber and Tsai Lyon, J.D., Barber, B.M., Tsai, C.-L., 1999. Improved Methods for Tests of Long-Run Abnormal Stock Returns. The Journal of Finance 54, 165-201., Mitchell \& Stafford Mitchell, M.L., Stafford, E., 2000. Managerial Decisions and Long-Term Stock Price Performance. Journal of Business 73, 287. and Loughran and Ritter Loughran, T., Ritter, J.R., 2000. Uniformly least powerful tests of market efficiency. Journal of Financial Economics 55, 361-389.
} 
The remainder of this paper is organised as follows: The next section briefly reviews the literature. Section 3 discusses specifications of the sample and method of the study. Section 4 presents and discusses the results and finally section 5 provides the conclusions.

\section{Literature review}

The literature on post-acquisition returns is extensive and goes back to Mandelker (1974). Tuch \& O'Sullivan (2007) summerise 14 studies since 1980 that measured long-term returns of acquisitions most of which report neutral or negative returns for acquirers. Zollo \& Meier (2008) also identify 17 studies that used metrics of long-term abnormal returns to measure acquisition performance. If we take into consideration that not all acquisitions perform unsatisfactorily, a number of studies examined the determinants of differential returns. These investigations suggest that acquirers abnormal returns can be explained through a renge of their characteristics such as size of acquirer (Moeller et al., 2004), method of payment (Loughran and Vijh, 1997; Savor and Lu, 2009) and mode of acquisition (Dong et al., 2006; Goergen and Renneboog, 2004).

Despite these findings the knowledge about acquisition returns across industries is limited to separate studies which do not address the questions about impact of industry on postacquisition returns. These studies typically investigate the post-completion performance of acquisitions in one particular industry or a number of related industries. These findings are inconsistent across industries. For instance, Boubakri et al. (2008) suggest that acquisitions in the property-liability insurance industry have positive and significant abnormal returns. The study investigated a sample of deals by US firms over the period of 1995 to 2000 and used buy-and-hold abnormal returns to detect the long-term abnormal performance of acquirers. Another study by Cummins and Xie (2008) on the US property-liability industry over a broader time interval from 1994 to 2003 supports this proposition. 
On the other hand, Laabs and Schiereck (2010) suggest that in the automotive supply industry acquirers experienced about $17 \%$ negative and significant post-completion buy-and-hold abnormal return over 36 months. They used a sample of acquisitions with acquirers from Europe, North and South America, and Asia which were completed during the period of 1981 to 2007. Moreover, Ferris and Park (2001) provide evidence that acquirers from the telecommunications industry suffer from about $20 \%$ statistically significant loss over 5 years post acquisition completion. They used long-term cumulative abnormal returns (CARs) and a sample of 516 acquisition deals in the telecommunication industry for the period 1990 to 1993.

In the banking industry, which has the highest rate of acquisition activity among industries, DeLong (2003) finds 1.1 percent statistically significant 3 years buy-and-hold abnormal returns for acquirers compare to the industry index. His sample of study consists of 54 completed bank mergers between 1991 and 1995.

Although the evidence from these studies suggests an overall discrepancy in acquirers' performance across different industries, a comprehensive study with comparable results for different industries can provide a more precise perception of the impact of industry on performance of acquirers. That is the purpose of this research.

\section{Data}

The sample in this study comprises 3101 completed acquisitions involving public companies listed on NYSE, AMEX and Nasdaq for which the effective date is between July 1981 and December 2007. In this paper acquisition is defined as takeover of at least $50 \%$ of shares of another firm where the acquirer owns at least $90 \%$ of the target shares afterwards. The List of completed mergers and acquisitions is drawn from the Securities Data Corporation (SDC) Platinum database, totaling 4143 acquisitions. The data of stock monthly returns, size and 
book-to-market ratio of acquirers are taken from Thomson Routers database. A total of 735 acquisitions are excluded from the analysis due to unavailability of lack of monthly stock returns data or acquirer's book or market value of equity. A further 213 acquisitions are excluded because of negative book value of equity of acquirers.

Acquirers of sample acquisitions at least have available stock prices 12 months post-merger. Where the acquirer is delisted after 12 month CARs and BHARs for the subsequent year is not available. Therefore, these acquisitions are not included in calculations of abnormal returns for the respective periods after delisting. i.e. firms which were delisted during 13 to 24 months after acquisition completion date are excluded from analysis of 24 (2) and 36 (3) months (years) CARs (BHARs) and those which were delisted after 25 months or more were excluded from analysis of 36 (3) months (years) CARs (BHARs).

The study uses the industry classification proposed by Fama and French (1997) to cluster acquisition deals into 48 industry groups ${ }^{3}$ based on 4 digits primary SIC codes. One third or sixteen industry groups are excluded from the analysis because of inadequate number of acquisition samples for statistical inference. The total number of acquisitions in these industries is 94 over the period of investigation, i.e. about 6 acquisitions per industry group. ${ }^{4}$ Therefore the sample acquisitions are clustered in 32 industry groups by acquirer industry. Figure 1 plots the annual number of acquisitions and their aggregate dollar value in 2010 dollars. The number and aggregate value of acquisitions both increase during the late 1990s and plunge during the early 2000 s.

\footnotetext{
${ }^{3}$ This classification consists of 48 industrial categories which are constructed based on 4 digit SIC codes and is popular in investigation of mergers and acquisitions Gorton, G., Kahl, M., Rosen, R.J., 2009. Eat or Be Eaten: A Theory of Mergers and Firm Size. The Journal of Finance 64, 1291-1344, Harford, J., 2005. What drives merger waves? Journal of Financial Economics 77, 529-560..

${ }^{4}$ The excluded industry groups are agriculture, alcoholic beverage, apparel, candy and soda, coal, defence, fabricated products, miscellaneous, non-metallic mining, precious metals, railroad equipment, real estate, rubber and plastic products, ship-building, shipping containers, textiles and tobacco products.
} 
Figure 1 - The number of acquisitions and the dollar value of acquisitions in 2010 US dollars. The Sample comprises 3101 acquisitions from 32 industry groups, completed from July 1981 to December 2011

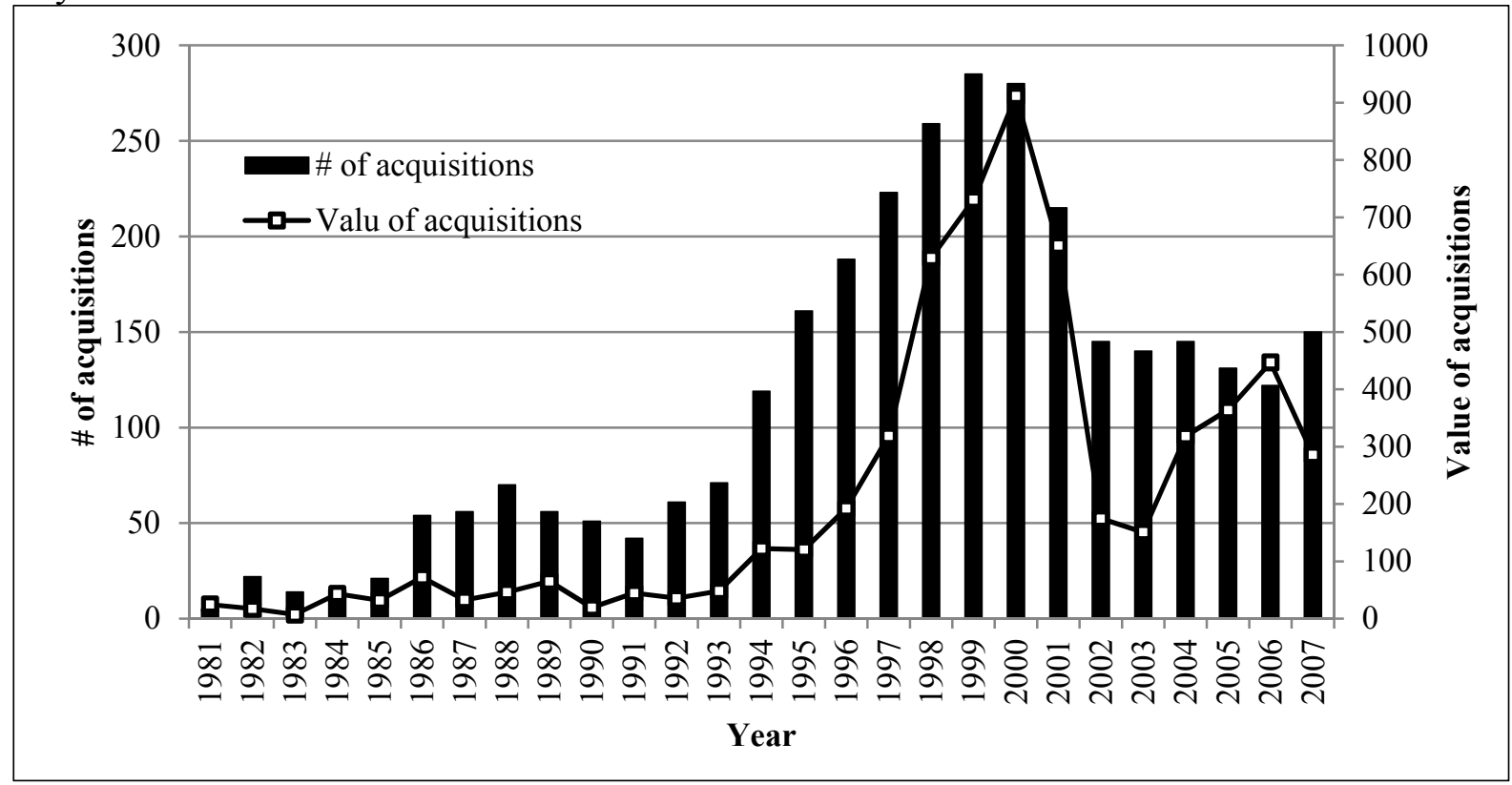

Table 1 reports the number and aggregate transaction value of acquisitions in 2010 dollars for 32 industry groups of the study. The total value of the sample acquisitions is $\$ 5906.1$ billion in 2010 dollars. First half (i.e. Top 16 industry groups) of

Table 1 holds $83.9 \%$ and $86.9 \%$ of the total number and the total value of acquisitions, respectively. Banking industry with the highest number and dollar value of acquisitions comprises $22.3 \%$ of the total number and $17.7 \%$ of the total value of acquisitions. Business services industry contains 408 acquisitions and is second in terms of number, but aggregate value of acquisitions of this group is third after the telecommunications industry which is ranked seventh in terms of number of acquisitions. In fact the highest average value of acquisitions belongs to the telecommunications industry with an average of USD 7.1 billion. Second, third and forth ranks are held by the petroleum and natural gas, aircraft and business supplies industries with $\$ 4$ billion, $\$ 3.2$ billion and $\$ 3$ billion, respectively. The average value of sample acquisitions is $\$ 1.9$ billion. 
Table 1

Number and dollar value of acquisitions by industry, July 1980 to December 2007

\begin{tabular}{|c|c|c|}
\hline & $\begin{array}{c}\text { \# of } \\
\text { Acquisitions }\end{array}$ & $\begin{array}{c}\text { Aggregate Value } \\
\text { (Billion } 2010 \text { USD) }\end{array}$ \\
\hline Banking & 692 & 1048.5 \\
\hline Business Services & 408 & 539.0 \\
\hline Trading & 185 & 226.8 \\
\hline Electronic Equipment & 171 & 209.4 \\
\hline Pharmaceutical Products & 157 & 388.1 \\
\hline Computers & 138 & 200.7 \\
\hline Telecommunications & 133 & 940.3 \\
\hline Petroleum and Natural Gas & 119 & 473.7 \\
\hline Retail & 108 & 185.0 \\
\hline Insurance & 106 & 352.6 \\
\hline Utilities & 97 & 232.3 \\
\hline Medical Equipment & 74 & 82.3 \\
\hline Wholesales & 70 & 81.0 \\
\hline Measuring and Control Equipment & 67 & 37.3 \\
\hline Healthcare & 58 & 95.4 \\
\hline Machinery & 52 & 39.9 \\
\hline Consumer Goods & 45 & 106.1 \\
\hline Restaurants, Hotel, Motel & 45 & 60.3 \\
\hline Transportation & 38 & 37.6 \\
\hline Construction Material & 37 & 27.9 \\
\hline Chemicals & 32 & 75.5 \\
\hline Business Supplies & 30 & 90.4 \\
\hline Food Products & 29 & 34.4 \\
\hline Steel Works, etc. & 29 & 34.7 \\
\hline Automobiles and Trucks & 26 & 29.3 \\
\hline Entertainment & 26 & 69.7 \\
\hline Aircraft & 24 & 76.5 \\
\hline Electrical Equipment & 24 & 38.7 \\
\hline Construction & 23 & 23.8 \\
\hline Recreational Products & 21 & 23.6 \\
\hline Printing and Publishing & 19 & 38.5 \\
\hline Personal Services & 18 & 6.9 \\
\hline Total & 3101 & 5906.1 \\
\hline
\end{tabular}




\section{Method}

\subsection{Construction of reference portfolios}

In order to compute the abnormal returns 50 reference portfolios are constructed based on size and book-to-market equity $(\mathrm{B} / \mathrm{M})$ ratio, regardless of the exchange. Firms listed on NYSE, AMEX and Nasdaq are ranked based on their June market value of equity. Size deciles are then created based on these rankings for all listed firms. Firms within each of the size deciles are then sorted based on their $\mathrm{B} / \mathrm{M}$ ratios in year $t-1$ and are divided into 5 quintiles based on these rankings. Firms with negative book value of equity are excluded from the analysis, though they are relatively rare. For each of the 50 size-B/M portfolios the monthly return is calculated as equally weighted average return of all securities in a particular portfolio.

Firm size is defined as the market value of common equity (the number of shares outstanding multiplied by price per share ${ }^{5}$ ) at the beginning of the month. The study follows Fama and French (1992, 1993), Barber and Lyon (1997) and Lyon et al (1999) and uses firm size in June of each year for size rankings during the following 12 months.

The study defines book equity as total assets, minus liabilities, plus balance sheet deferred taxes and investment tax credit (when available), minus preferred stocks redemption value (if available). If total asset is missing, total shareholders' equity is substituted. The book-tomarket equity ratio for year $t$ is calculated as the book equity for the fiscal year end for calendar year $t$ divided by market equity at the end of December of year $t$.

\footnotetext{
${ }^{5}$ Where this was not available the Market Capitalization item from Thomson Reuter database is substituted.
} 


\subsection{Long-term abnormal returns}

Variations of CARs and BHARs are used in previous research on post-completion returns of acquisitions. In this research, both CARs and BHARs are measured to determine long-term abnormal returns of acquirers.

For a sample firm cumulative abnormal return after $\tau$ month is computed as:

$$
C A R_{i t}=\sum_{t=1}^{\tau}\left[R_{i t}-E\left(R_{i t}\right)\right]
$$

Also, for each sample acquirer buy-and-hold abnormal returns after $\tau$ years are calculated as:

$$
B H A R_{i \tau}=\prod_{t=1}^{\tau}\left[1+R_{i t}\right]-\prod_{t=1}^{\tau}\left[1+E\left(R_{i t}\right)\right]
$$

Where $R_{i t}$ is the return for security $i$ in month $t$, and $E\left(R_{i t}\right)$ is the expected return for security $i$ in month $t$. The expected returns are calculated as rebalanced return on a size-B/M reference portfolio 12, 24 and 36 months post-acquisition. This research follows Lyon et al. (1999) in the calculation of rebalanced portfolio returns.

\section{Empirical Findings}

The findings of the research about mean abnormal returns of acquisitions are consistent with the literature: on average, long-term abnormal return of acquirers is less than or equal with zero. Table 2 reports the mean abnormal returns. Twelve month (1 year) abnormal returns measured by CARs and BHARs are around zero. Longer horizon abnormal returns are negative and statistically significant. Twenty four months mean CAR and 2 years mean BHAR are -2.72 and -2.77 percent, respectively. Thirty six months mean CAR and 2 years mean BHAR are - 4.84 and -7.18 percent, in order. 
Table 2

Mean abnormal returns for acquirers

\begin{tabular}{|c|c|c|c|}
\hline & \multicolumn{3}{|c|}{ Time horizon } \\
\hline & 12 months/ 1 years & 24 months/ 2 years & 36 months/ 3 years \\
\hline Sample size & 3101 & 2966 & 2829 \\
\hline Mean CAR & -0.0085 & $-0.0272 * *$ & $-0.0484 * * *$ \\
\hline Mean BHAR & -0.0033 & $-0.0277 *$ & $-0.0718 * * *$ \\
\hline
\end{tabular}

$*, * *, * * *$ significantly different from zero at the $10 \%, 5 \%$ and $1 \%$ levels, respectively.

\subsection{Mean post-acquisition returns within different industries}

The results of the study provide evidence of discrepancy in acquirers' returns across industries. While a number of groups such as petroleum and natural gas, insurance and machinery industries show positive long-term abnormal returns, most of them propose negative performance for acquirers compare to non-acquirer firms. Also, there are a number of industries that shows fluctuations in long-term abnormal returns.

Findings for the banking industry are consistent with the extant literature in the acquisition arena (e.g. DeLong, 2003), abnormal returns of acquirers are more or less around zero. The only exception is 36 months CAR with - 4.56 percent.

In the business services industry CARs are found to be significantly negative but mean abnormal returns rebound gradually. Twelve, 24 and 36 months mean CARs are $-9.02,-8.06$ and - 2.86 percent, respectively. These figures indicate that abnormal returns during the second and the third year compensated much of the loss of the after acquisition year. Nevertheless, BHARs indicate that long-term investors had a different experience. Although loss of the first year is compensated during the second year, three years mean BHAR is 8.82 percent.

Trading and electronic equipment industries show similar trends. The acquirers from these industries continuously gain negative abnormal returns over the three years horizon. For trading industry 12,24 and 36 months CARs are $-2.30,-3.07$ and -7.34 percent, 
respectively. BHARs are similar. In electronic equipment industry CARs are $-2.86,-4.59$, and - 5.04 percent, in order. However, the slope of abnormal losses for long-term investors is steeper. Three years BHAR for the industry is -25.40 percent and significant.

Table 3

Mean abnormal returns of acquirers in different industries, July 1981 - December 2007

\begin{tabular}{|c|c|c|c|c|c|c|}
\hline \multirow{2}{*}{ Industry description } & \multicolumn{3}{|c|}{ Cumulative abnormal returns } & \multicolumn{3}{|c|}{$\begin{array}{c}\text { Buy-and-hold abnormal } \\
\text { returns }\end{array}$} \\
\hline & $\begin{array}{c}12 \\
\text { months } \\
\end{array}$ & $\begin{array}{c}24 \\
\text { months } \\
\end{array}$ & $\begin{array}{c}36 \\
\text { months } \\
\end{array}$ & $\begin{array}{c}1 \\
\text { year }\end{array}$ & $\begin{array}{c}2 \\
\text { years } \\
\end{array}$ & $\begin{array}{c}3 \\
\text { years } \\
\end{array}$ \\
\hline Banking & 0.0040 & -0.0094 & -0.0459 & 0.0050 & 0.0002 & 0.0043 \\
\hline Business Services & $-0.0902 * * *$ & $-0.0806 * * *$ & $-0.0286^{* *}$ & -0.0720 & 0.0070 & $-0.0882 *$ \\
\hline Trading & -0.0230 & -0.0307 & -0.0734 & -0.0161 & -0.0261 & -0.0623 \\
\hline Electronic Equipment & -0.0286 & -0.0459 & -0.0504 & 0.0059 & -0.0759 & $-0.2540 * * *$ \\
\hline $\begin{array}{l}\text { Pharmaceutical } \\
\text { Products }\end{array}$ & $0.1405^{* * *}$ & $0.1337 * * *$ & $0.0493 * *$ & 0.1433 & 0.0243 & -0.1070 \\
\hline Computers & -0.0046 & -0.0679 & 0.0145 & $0.0058^{*}$ & -0.1369 & -0.0718 \\
\hline Telecommunications & $-0.0891 * *$ & -0.2004 & $-0.4019 * * *$ & -0.0308 & $-0.1044 * * *$ & $-0.2288 * *$ \\
\hline $\begin{array}{l}\text { Petroleum and Natural } \\
\text { Gas }\end{array}$ & $0.0743 *$ & 0.1368 & $0.1500^{* *}$ & $0.0632 *$ & $0.1281 *$ & 0.1336 \\
\hline Retail & -0.0541 & -0.0708 & -0.1006 & 0.0314 & -0.0498 & -0.0543 \\
\hline Insurance & 0.0732 & 0.1056 & 0.0689 & 0.0631 & 0.0883 & 0.0629 \\
\hline Utilities & -0.0318 & -0.0606 & -0.1289 & -0.0266 & -0.0705 & $-0.1641 *$ \\
\hline Medical Equipment & 0.0090 & -0.0367 & -0.0651 & -0.0013 & -0.0855 & -0.1793 \\
\hline Wholesales & -0.0355 & -0.0989 & -0.1428 & -0.0511 & -0.1451 & -0.1630 \\
\hline $\begin{array}{l}\text { Measuring and Control } \\
\text { Equipment }\end{array}$ & 0.0745 & 0.0754 & 0.0870 & 0.0327 & -0.0247 & -0.0134 \\
\hline Healthcare & -0.0994 & $-0.3254 * *$ & $-0.1085 * * *$ & $-0.1395 * *$ & -0.2639 & -0.1420 \\
\hline Machinery & 0.0580 & 0.1302 & 0.1739 & $0.0782 * *$ & 0.2431 & 0.2254 \\
\hline Consumer Goods & 0.0630 & 0.0379 & -0.0525 & 0.0644 & 0.0010 & -0.0846 \\
\hline $\begin{array}{l}\text { Restaurants, Hotel, } \\
\text { Motel }\end{array}$ & -0.0845 & -0.0436 & -0.1356 & -0.0977 & -0.1446 & $-0.2959 * *$ \\
\hline Transportation & -0.0045 & -0.0190 & -0.0181 & -0.0248 & -0.1159 & -0.1368 \\
\hline Construction Material & 0.0417 & -0.1035 & -0.2790 & -0.0169 & $-0.1983 * *$ & $-0.3674 * *$ \\
\hline Chemicals & -0.1092 & -0.1368 & -0.2736 & -0.1367 & $-0.1610^{*}$ & -0.2827 \\
\hline Steel Works, etc. & -0.0506 & -0.3043 & $-0.2771 * *$ & $-0.0742 * *$ & $-0.3134^{*}$ & $-0.4616^{* *}$ \\
\hline Business Supplies & 0.0379 & 0.0426 & 0.0374 & 0.0219 & -0.0048 & -0.0278 \\
\hline Food Products & 0.0332 & 0.2138 & $0.2614^{*}$ & 0.0127 & $0.0685^{*}$ & 0.1801 \\
\hline $\begin{array}{l}\text { Automobiles and } \\
\text { Trucks }\end{array}$ & 0.0061 & -0.0647 & -0.0705 & 0.0256 & -0.0462 & -0.1613 \\
\hline Entertainment & 0.0523 & 0.1892 & 0.1178 & -0.0289 & 0.1720 & 0.0183 \\
\hline Aircraft & -0.0448 & -0.0576 & -0.1103 & -0.0447 & -0.1176 & -0.1350 \\
\hline Electrical Equipment & 0.0659 & 0.0857 & 0.1926 & 0.0389 & 0.1058 & 0.2970 \\
\hline Construction & -0.0181 & -0.0835 & -0.0467 & -0.0389 & -0.0434 & $0.3762 *$ \\
\hline Recreational Products & 0.0323 & -0.0905 & -0.0898 & -0.0419 & -0.0003 & -0.0639 \\
\hline $\begin{array}{l}\text { Printing and } \\
\text { Publishing }\end{array}$ & 0.0024 & -0.0586 & -0.4248 & -0.0009 & $-0.0305 * *$ & -0.1274 \\
\hline Personal Services & -0.0485 & -0.2573 & -0.2071 & -0.0259 & -0.3098 & -0.2683 \\
\hline Banking & 0.0040 & -0.0094 & -0.0459 & 0.0050 & 0.0002 & 0.0043 \\
\hline Business Services & $-0.0902 * * *$ & $-0.0806 * * *$ & $-0.0286^{* *}$ & -0.0720 & 0.0070 & $-0.0882 *$ \\
\hline
\end{tabular}

$*, * *, * * *$ significantly different from zero at the $10 \%, 5 \%$ and $1 \%$ levels, respectively. 
Pharmaceutical Products industry show significant gains during the first 12 months. However, these positive gains disappear during the second and the third year after acquisitions. Twelve, 24 and 36 months CARs are 14.05, 13.37 and 4.93 percent, respectively. This observation indicates a significant decrease in expected abnormal returns during the third post-acquisition year for the acquirers. The experience of long-term investors is even worse. Three years mean BHAR is -10.70 percent.

The computers industry starts with neutral abnormal return during the first year. CARs and BHARs both plunge during the second year and then rebound during the third year. Mean CARs are $-0.46,-6.79$ and 1.45 percent. Mean BHARs are 0.58, - 13.69 and -7.18 percent.

Consistent with the literature, abnormal returns are significantly negative in the telecommunications industry. Twelve, 24 and 36 months mean CARs are $-8.91,-20.04$ and - 40.19 percent, respectively. The figures indicate a persistent abnormal loss over the 36 month horizon. One, two and three years BHARs are - 3.08, -10.44 and -22.88 percent, correspondingly.

The petroleum and natural gas industry shows positive and significant abnormal returns and continuous abnormal gains over the 3 years horizon. Twelve, 24 and 36 months mean CARs are 7.43, 13.68 and 15.00 percent, respectively. One, 2 and 3 years BHARs are 6.32, 12.81 and 13.36 percent, correspondingly.

\subsection{Test of equality of mean abnormal returns}

In order to test the null hypothesis that the mean abnormal returns are equal across industry groups the research conducts both ANOVA and Welch F-tests. For brevity, only the results of Welch test, which allows for unequal number of samples in different industries, is reported, although the results are robust for ANOVA F-test. The results are presented in Table 4. Except for 1 year BHAR the results of Welch F-test rejects the null hypothesis that means 
abnormal returns are equal across industries. Therefore, at least there is one industry which has different long term abnormal returns than other industries.

Table 4

Significance of difference in mean abnormal returns

\begin{tabular}{|c|c|c|c|c|c|c|}
\hline \multirow{2}{*}{ Method } & \multicolumn{2}{|c|}{1 year } & \multicolumn{2}{|c|}{2 years } & \multicolumn{2}{|c|}{3 years } \\
\hline & F (Diff.) & p-value & F (Diff.) & p-value & F (Diff.) & p-value \\
\hline \multicolumn{7}{|c|}{ Panel A - Cumulative abnormal Returns } \\
\hline Welch F-test & $1.6470 * *$ & 0.0171 & $2.2883 * * *$ & 0.0001 & $2.1520 * * *$ & 0.0004 \\
\hline \multicolumn{7}{|c|}{ Panel B - Buy and hold abnormal returns } \\
\hline Welch F-test & 1.1245 & 0.2980 & $1.5366^{* *}$ & 0.0348 & $1.9132 * * *$ & 0.0027 \\
\hline
\end{tabular}

$*, * *, * * *$ statistically significant at the $10 \%, 5 \%$ and $1 \%$ levels, respectively.

\subsection{Difference of returns across industries}

To further examine the significance of different post-merger returns across industries this paper tests the equality of means for 496 pairs of industries. A Satterthwaite-Welch $t$-test is employed to test the significance of difference. The evidence suggests that in 241 pairs, the mean abnormal performances of two industries are significantly different at least in one of 1 , 2 or 3 years CARs or BHARs. Twelve months mean CARs are significantly different for 70 pairs of industries. The differences between 24 months mean CARs are statistically significant for 139 pairs. Also, 36 months mean CARs are significantly different for 122 pairs. One-year mean BHARs are significantly different for 49 pairs of industries. The difference between 2-year mean BHARs are statistically significant for 92 pairs. Finally, 3 year mean BHARs are significantly different for 114 pairs.

For brevity the results of equality tests are only reported for 31 pairs which include the banking industry, for example. All other test results are available upon request. Table 5 presents the mean abnormal return for the other 31 industries compared to the banking industry. These findings provide evidence to show that the average abnormal returns of the banking industry is significantly different from a number of other industries. For example, in 
terms of CARs pharmaceutical products outperform banking industry in both economically and statistically significant levels.

Table 5

Difference of mean CARs and mean BHARs between banking and other industries

\begin{tabular}{|c|c|c|c|c|c|c|}
\hline \multirow[b]{2}{*}{ Industry description } & \multicolumn{3}{|c|}{ Difference between CARs } & \multicolumn{3}{|c|}{ Difference between BHARs } \\
\hline & $\begin{array}{c}12 \\
\text { months }\end{array}$ & $\begin{array}{c}24 \\
\text { months }\end{array}$ & $\begin{array}{c}36 \\
\text { months }\end{array}$ & $\begin{array}{c}1 \\
\text { year }\end{array}$ & $\begin{array}{c}2 \\
\text { years }\end{array}$ & $\begin{array}{c}3 \\
\text { years }\end{array}$ \\
\hline Business Services & $-0.0942 * *$ & -0.0712 & 0.0173 & $-0.0770 * *$ & 0.0067 & -0.0925 \\
\hline Trading & -0.027 & -0.0213 & -0.0275 & -0.0211 & -0.0264 & -0.0666 \\
\hline Electronic Equipment & -0.0327 & -0.0365 & -0.0044 & 0.0009 & -0.0762 & $-0.2583 * * *$ \\
\hline $\begin{array}{l}\text { Pharmaceutical } \\
\text { Products }\end{array}$ & $0.1365 * * *$ & $0.1431 * * *$ & $0.0953 *$ & $0.1383 * *$ & 0.0241 & $-0.1113 *$ \\
\hline Computers & -0.0087 & -0.0585 & 0.0605 & 0.0008 & -0.1372 & -0.0761 \\
\hline Telecommunications & $-0.0932 *$ & $-0.1909 * *$ & $-0.3559 * * *$ & -0.0358 & -0.1046 & $-0.2331 * *$ \\
\hline $\begin{array}{l}\text { Petroleum and } \\
\text { Natural Gas }\end{array}$ & 0.0702 & $0.1463 * *$ & $0.1959 * *$ & 0.0582 & 0.1278 & 0.1292 \\
\hline Retail & -0.0582 & -0.0613 & -0.0547 & 0.0264 & -0.0501 & -0.0586 \\
\hline Insurance & $0.0691^{* *}$ & $0.1151 * *$ & 0.1148 & 0.0581 & 0.0881 & 0.0585 \\
\hline Utilities & -0.0359 & -0.0511 & -0.083 & -0.0316 & -0.0707 & $-0.1685 * *$ \\
\hline Medical Equipment & 0.0049 & -0.0272 & -0.0191 & -0.0063 & -0.0858 & $-0.1837 *$ \\
\hline Wholesales & -0.0396 & -0.0894 & -0.0968 & -0.0561 & -0.1454 & -0.1673 \\
\hline $\begin{array}{l}\text { Measuring and } \\
\text { Control Equipment }\end{array}$ & 0.0704 & 0.0848 & $0.1330 * *$ & 0.0277 & -0.025 & -0.0177 \\
\hline Healthcare & $-0.1035^{*}$ & $-0.3160 * * *$ & -0.0626 & $-0.1445^{* *}$ & $-0.2642 * *$ & -0.1463 \\
\hline Machinery & 0.0539 & 0.1396 & $0.2199 *$ & 0.0732 & 0.2428 & 0.2211 \\
\hline Consumer Goods & 0.0589 & 0.0474 & -0.0066 & 0.0594 & 0.0008 & -0.089 \\
\hline $\begin{array}{l}\text { Restaurants, Hotel, } \\
\text { Motel }\end{array}$ & -0.0886 & -0.0341 & -0.0896 & -0.1027 & -0.1449 & -0.3003 \\
\hline Transportation & -0.0086 & -0.0095 & 0.0278 & -0.0298 & -0.1161 & -0.1411 \\
\hline Construction Material & 0.0376 & -0.094 & $-0.2330 * *$ & -0.0219 & $-0.1985 * *$ & $-0.3717 * * *$ \\
\hline Chemicals & $-0.1132 *$ & -0.1273 & -0.2277 & $-0.1417 *$ & -0.1613 & -0.287 \\
\hline Business Supplies & 0.0339 & 0.052 & 0.0834 & 0.0169 & -0.005 & -0.0321 \\
\hline Food Products & 0.0291 & $0.2232 * *$ & $0.3073 * * *$ & 0.0077 & 0.0683 & 0.1758 \\
\hline Steel Works, etc. & -0.0547 & $-0.2948 * *$ & $-0.2312^{*}$ & -0.0792 & $-0.3136 * * *$ & $-0.4659 * * *$ \\
\hline $\begin{array}{l}\text { Automobiles and } \\
\text { Trucks }\end{array}$ & 0.002 & -0.0553 & -0.0246 & 0.0206 & -0.0465 & -0.1657 \\
\hline Entertainment & 0.0482 & $0.1987 *$ & 0.1638 & -0.0339 & 0.1718 & 0.014 \\
\hline Aircraft & -0.0489 & -0.0482 & -0.0644 & -0.0497 & -0.1179 & -0.1393 \\
\hline Electrical Equipment & 0.0618 & 0.0952 & $0.2385^{*}$ & 0.0339 & 0.1055 & 0.2927 \\
\hline Construction & -0.0222 & -0.074 & -0.0007 & -0.0439 & -0.0437 & 0.3719 \\
\hline Recreational Products & 0.0282 & -0.0811 & -0.0438 & -0.0469 & -0.0006 & -0.0682 \\
\hline $\begin{array}{l}\text { Printing and } \\
\text { Publishing }\end{array}$ & -0.0016 & -0.0492 & -0.3789 & -0.0059 & -0.0307 & -0.1317 \\
\hline Personal Services & -0.0526 & $-0.2479 *$ & -0.1611 & -0.0309 & $-0.3101^{*}$ & -0.2726 \\
\hline
\end{tabular}

$*, * *, * * *$ statistically significant at the $10 \%, 5 \%$ and $1 \%$ levels, respectively. 
Twelve, 24 and 36 month mean CARs are respectively 13.65, 14.31 and 9.53 percent higher for pharmaceutical products. On the other hand, acquirers from telecommunications industry underperform banking acquirers in terms of CARs. Twelve, 24 and 36-months BHARs of telecommunications are 9.32, 19.09 and 35.59 percent lower than banking industry, respectively.

\section{Conclusions}

This paper investigates the industry impact on post acquisition performance of acquirers. The results of this research provides more comprehensive evidence from all of the industries which have been involved in mergers and acquisition deals during the period of 1981 to 2007 so that the returns of different industries can be compared. Most importantly, the evidence rejects the equality of mean abnormal returns across industries at significant levels. This is consistent with evidences from extant literature which show unequal long-term performance across industries.

The results of the study propose discrepancy in acquirers' long-term abnormal returns across industries. While a number of industries such as petroleum and natural gas, insurance and machinery, experienced significantly positive abnormal performance, others like business services and medical equipment have demonstrated significantly negative long-term returns. Consistent with prior research findings, the results of this study suggest around zero longterm performance for acquisitions in the banking industry. The banking industry is especially important because of the relatively large number of acquisition deals that have been completed in this industry over the past three decades.

These results point to the potential fruitful further research investigating the characteristics of industries which further explain the difference in abnormal returns of acquirers. In other words, a number of common industry characteristics that may impact acquisition 
performance, can be the subject of future studies. These characteristics should add to the explanation of differential acquirers' abnormal returns.

\section{References}

Barber, B.M., Lyon, J.D., 1997. Detecting long-run abnormal stock returns: The empirical power and specification of test statistics. Journal of Financial Economics 43, 341-372.

Boubakri, N., Dionne, G., Triki, T., 2008. Consolidation and value creation in the insurance industry: The role of governance. Journal of Banking \& Finance 32, 56-68.

Cummins, J.D., Xie, X., 2008. Mergers and acquisitions in the US property-liability insurance industry: Productivity and efficiency effects. Journal of Banking \& Finance 32, 30-55.

DeLong, G., 2003. Does Long-Term Performance of Mergers Match Market Expectations? Evidence from the US Banking Industry. Financial Management (Blackwell Publishing Limited) 32, 5.

Dong, M., Hirshleifer, D., Richardson, S., Teoh, S.H., 2006. Does Investor Misvaluation Drive the Takeover Market? The Journal of Finance 61, 725-762.

Fama, E.F., 1998. Market efficiency, long-term returns, and behavioral finance. Journal of Financial Economics 49, 283-306.

Fama, E.F., French, K.R., 1992. The Cross-Section of Expected Stock Returns. The Journal of Finance 47, 427-465.

Fama, E.F., French, K.R., 1993. Common risk factors in the returns on stocks and bonds. Journal of Financial Economics 33, 3-56.

Fama, E.F., French, K.R., 1997. Industry costs of equity. Journal of Financial Economics 43, 153-193.

Ferris, S.P., Park, K., 2001. How Different is the Long-Run Performance of Mergers in the Telecommunications Industry? Innovations in Investments and Corporate Finance Volume 7, pages 127-144.

Goergen, M., Renneboog, L., 2004. Shareholder Wealth Effects of European Domestic and Crossborder Takeover Bids. European Financial Management 10, 9-45.

Gorton, G., Kahl, M., Rosen, R.J., 2009. Eat or Be Eaten: A Theory of Mergers and Firm Size. The Journal of Finance 64, 1291-1344.

Harford, J., 2005. What drives merger waves? Journal of Financial Economics 77, 529-560.

Kothari, S.P., Warner, J.B., 1997. Measuring long-horizon security price performance. Journal of Financial Economics 43, 301-339.

Laabs, J.-P., Schiereck, D., 2010. The long-term success of M\&A in the automotive supply industry: determinants of capital market performance. Journal of Economics and Finance 34, 61-88.

Loughran, T., Ritter, J.R., 2000. Uniformly least powerful tests of market efficiency. Journal of Financial Economics 55, 361-389.

Loughran, T., Vijh, A.M., 1997. Do Long-Term Shareholders Benefit From Corporate Acquisitions? The Journal of Finance 52, 1765-1790.

Lyon, J.D., Barber, B.M., Tsai, C.-L., 1999. Improved Methods for Tests of Long-Run Abnormal Stock Returns. The Journal of Finance 54, 165-201. 
Mandelker, G., 1974. Risk and return: The case of merging firms. Journal of Financial Economics 1, 303-335.

Mitchell, M.L., Stafford, E., 2000. Managerial Decisions and Long-Term Stock Price Performance. Journal of Business 73, 287.

Moeller, S.B., Schlingemann, F.P., Stulz, R.M., 2004. Firm size and the gains from acquisitions. Journal of Financial Economics 73, 201-228.

Savor, P.G., Lu, Q.I., 2009. Do Stock Mergers Create Value for Acquirers? Journal of Finance 64, 10611097.

Tuch, C., O'Sullivan, N., 2007. The impact of acquisitions on firm performance: A review of the evidence. International Journal of Management Reviews 9, 141-170.

Zollo, M., Meier, D., 2008. What Is M\&A Performance? Academy of Management Perspectives 22, 55-77. 